http://journal.uinsgd.ac.id/index.php/biodjati

\title{
THE FISH FAUNA IN LAKITAN RIVER, MUSI RAWAS REGENCY, SOUTH SUMATRA
}

\author{
Dian Samitra*1, Zico Fakhrur Rozi
}

\begin{tabular}{l}
\hline Received : January 30, 2019 \\
Accepted : February 24, 2019 \\
\hline DOI: 10.15575/biodjati.v4i1.4097 \\
\hline 1,2Biology of Education, STKIP PGRI \\
Lubuklinggau. Jl. Mayor Toha, Kelu- \\
rahan Air Kuti, Lubuklinggau 31626, \\
telp. 0733-451432
\end{tabular}

e-mail:

${ }^{* 1}$ dian.samitra@gmail.com

zico.fakhrurrozi@gmail.com

*Corresponding author

\begin{abstract}
Fish diversity in the Lakitan River is not well recorded, even though the data is important to add information about the diversity of freshwater fish in Indonesia. This study aims to study fish composition and ecological index in the Lakitan River. The study was conducted in the Lakitan River, Musi Rawas Regency, South Sumatra Province. The method used was the survey method. The direct sampling was done at 5 stations, the numbering of stations followed the direction of the river from upstream to downstream. The data at each station are tabulated based on species, family and order. Data analysis includes a diversity index, evenness index, dominance index, and similarity index. The fish caught during the study were 418 individuals, which were identified into 20 species and 11 families. Barbonymus gonionotus is the most captured species in the Lakitan River. Cyprinidae is the most captured family (9 species). The highest diversity index was found at station 5, with the number of fish collected was 16 species. The evenness index at 5 stations showed the equivalent species distribution and stable communities. The domination index at 5 stations were at, low category. The similarity index between stations in Lakitan River which ranging from $0.65-0.97$. These results indicate that fish diversity in the Lakitan River medium biodiversity.
\end{abstract}

Keywords: fish, fauna, Lakitan River, Musi Rawas Regency, South Sumatera.

\section{Citation}

Samitra, D. \& Rozi, Z. F. (2019). The Fish Fauna in Lakitan River, Musi Rawas Regency, South Sumatra. Jurnal Biodjati, 4(1), 11-20

\section{INTRODUCTION}

The Lakitan River is one of the rivers in South Sumatra Province of Indonesia. It flows $1.113 \mathrm{KM}^{2}$ from Bengkulu Province as upstream and empties into the Musi River (Emilia et al., 2013; Badan Pusat Statistik Provinsi Sumatera Selatan, 2019). The Lakitan River has been built by The Lakitan Dam (Berita Satu, 2015).

Information from respondents stated that over the past 5 years fish catches in the Lak- itan River have been reduced and some species have rarely been caught. Decreasing fish populations in the Lakitan River due to overfishing. In addition, several results of the study statethat a decrease fish is caused by damage to the environment and human activities (Hossain et al., 2017; Guo et al., 2018). Lack of information and knowledge related to the fish in the river makes people less concerned about maintaining habitat and fish populations. Information about the fish in the waters is very necessary due to the fish population 


\section{Jurnal Biodjati 4(1):11-20, May 2019 \\ JURNAL BI@DIATI}

http://journal.uinsgd.ac.id/index.php/biodjati

changes from time to time (Purwanto et al., 2014). Study on fish diversity in several rivers of South Sumatra Province has been conducted such as in the Musi River, Palembang (Eddy, 2013) and research on fish diversity in the Kelingi River Lubuklinggau and Musi Rawas (Samitra \& Rozi, 2018a; Samitra, et al., 2018). Samitra \& Rozi (2018b) have been conducted research at the Lakitan Dam located in the Lakitan River. However, information about fish diversity in the Lakitan River is still limited. Research in the Lakitan River is important to add information regarding the diversity of freshwater fish. The aims of this study to asses the fish composition and ecological aspect the Lakitan River.

\section{MATERIALS AND METHODS}

\section{Site Study}

The study was conducted in the Lakitan River, Musi Rawas Regency, South Sumatra Province, from January to May 2018. The coordinates and map location of the study in Figure 1.

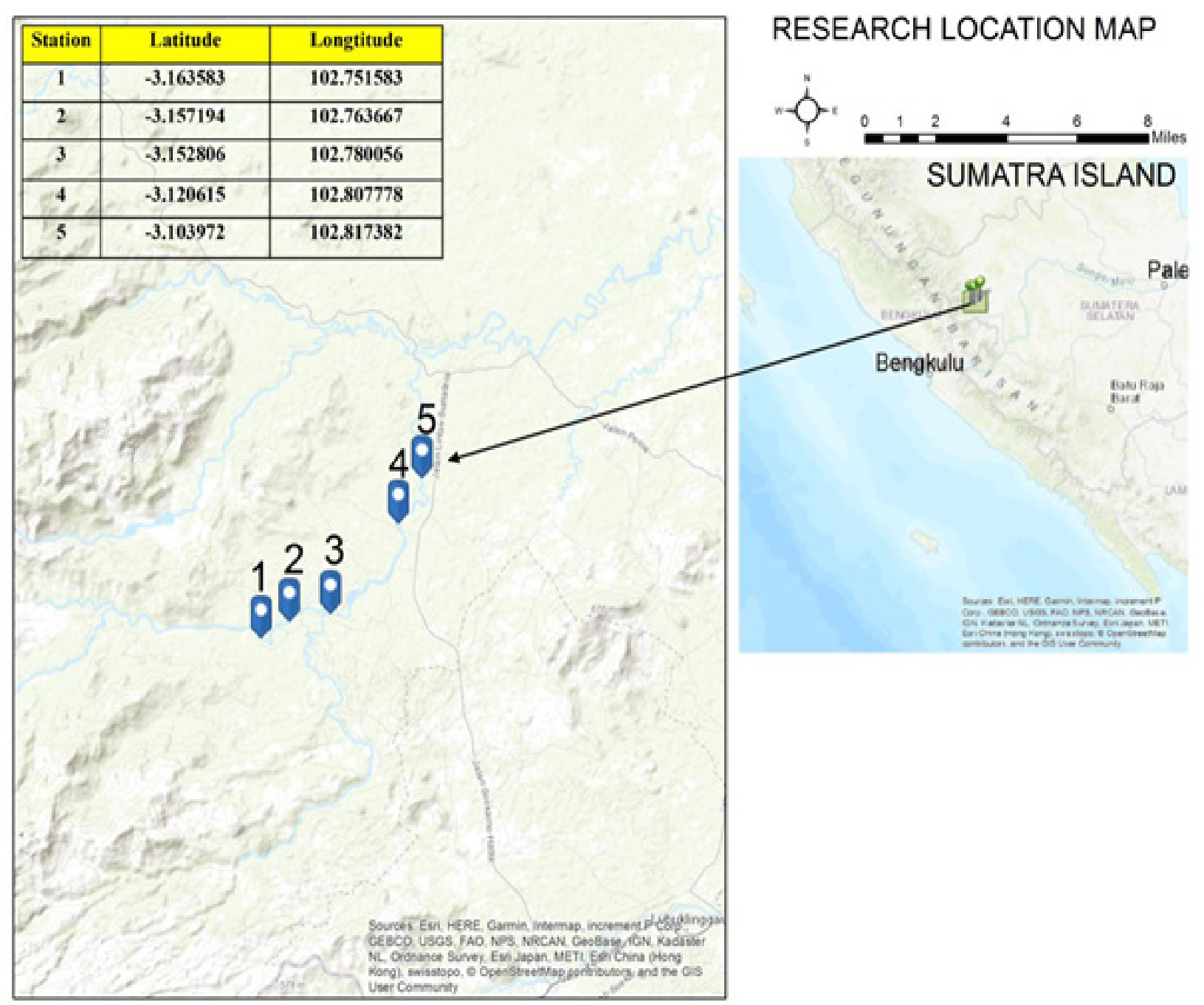

Figure 1. Research Location in the Lakitan River (Arcgis 10.2) 


\section{Jurnal Biodjati 4(1):11-20, May 2019 \\ JURNAL BI@DIATI}

http://journal.uinsgd.ac.id/index.php/biodjati

\section{Sampling Methods}

The tools used in sampling are GPS, $\mathrm{pH}$, DO meter, thermometer, cast net $1 / 2$ inch for small fish and 1 1/2 inch for big fish, dikes, stationery, ruler, spuit $3 \mathrm{ml}$ and digital cameras. The materials needed are plastic bags, label paper and $4 \%$ formalin. The survey method was used in this research. Direct sampling was carried out at 5 stations, selected by the purposive sampling station based on safety considerations and water conditions. The station numbering based on the direction of the river from upstream to downstream (Samitra \& Rozi, 2018a). Before taken the sample, measurements of abiotic factor data in the Lakitan River included: water temperature, $\mathrm{pH}$ and Dissolved Oxygen (DO). Sampling in each station is done three times. Samples were obtained using scatter and dikes. Fish caught photographed using a digital camera, then samples are preserved and put into plastic bags containing 4\% formalin and labeled. Specifically for the large or thick-bodied fish samples, the formalin needs to be injected through anal (Hadiaty, 2011). The fish samples obtained were then taken to the STKIP PGRI Lubuklinggau Biology Education laboratory to be identified.

\section{Laboratory Activities}

Bottle collection and trays are tools used in laboratory activities. The material used is tap water and $70 \%$ alcohol. Fish samples were removed from formalin plastic bags and then soaked in water for several hours. The fish samples were sorted morphologically and put into a collection bottle containing $70 \%$ alcohols (Hadiaty, 2011). Identification activities were carried out in a laboratory based on Kottelat et al. (1993), Iqbal (2011) and Sukmono \& Margaretha (2017).

\section{Data Analysis}

Fish data at each station ware tabulated based on species, family, and order. Data analysis includes a diversity index, evenness index, dominance index, and similarity index. The calculation of diversity index aimed to determine diversity in a community (Pratami et al., 2018).

Diversity index is calculated using the Shannon-Wienner (Hossain et al., 2017; Guo et al., 2018).

$$
H^{\prime}=-\sum(n 1 / N) \times \ln (n 1 / N)
$$

Where $H^{\prime}=$ diversity index, $\mathrm{n} 1=$ number of type $\mathrm{i}$ individuals, $\mathrm{N}=$ number of individuals of all types. The criteria for diversity index are as follows: $\mathrm{H}^{\prime} \leq 2.0$ low category, $2.0<\mathrm{H}^{\prime}$ $\leq 3.0$ is a medium category and $\mathrm{H}^{\prime} \geq 3.0$ is a high category (Rappe, 2010).

Evenness index shows the evenness pattern of distribution of biota, (Rahman \& Mujiyanto, 2013). The uniformity index value (E) using the Pielou evenness index (Hossain et al., 2017; Guo et al., 2018).

\section{$\mathbf{E}=\mathbf{H}^{\prime} / \operatorname{lnS}$}

Where, $\mathrm{E}=$ evenness index type, $\mathrm{H}^{\prime}=$ index of diversity and $\mathrm{S}=$ Number of types found. If the value of evenness index approaches 0 , it can be interpreted that there is a tendency for dominance of certain species in the ecosystem/community, and if the value approaches 1 then the ecosystem/community is in a relatively stable condition and the spread of species is evenly distributed (Rahman \& Mujiyanto, 2013).

Dominance index is calculated using the Simpson dominance index (Hossain et al., 2017; Guo et al., 2018).

$$
\mathbf{C}=\sum(\mathbf{n i} / \mathbf{N})
$$

Where $\mathrm{C}=$ dominance index, $\mathrm{ni}=$ number of individual species $\mathrm{i}, \mathrm{N}=$ total number of indi- 


\section{JURNAL BIDDJATI}

http://journal.uinsgd.ac.id/index.php/biodjati

viduals of all species. The dominance index criteria are as follows: $0.00<\mathrm{C} \leq 0.5$ low category, $0.5>\mathrm{C} \leq 0.75$ medium category and 0.75 $<\mathrm{C} \leq 1$ high category (Rappe, 2010). Type similarity index is used to determine the level of similarity of fish between 2 communities.

The similarity index value is calculated using the similarity Jaccard index (Negi \& Mamgain, 2013).

\section{$\mathbf{C J}=\mathbf{j} /(\mathbf{a}+\mathbf{b}-\mathbf{j})$}

Where $\mathrm{Cj}$ : Similarity between any two zones a and; -j: Number of species common to both zones a and $b$; $a$ : number. of species at zone $\mathrm{a} ; \mathrm{b}$ : no. of species at zone $\mathrm{b}$. If $\mathrm{Cj}$ is 1 , it can be interpreted that there is complete similarity whereas 0 is complete dissimilarity.

\section{RESULTS AND DISCUSSION}

\section{Fish Composition}

A total of 418 fish belonging to 20 species and 11 families obtained. Cyprinidae is a family that dominates the catch on the Lakitan River. Station 5 is the most found location of fish with 177 fish which belonged to 16 species. The distribution of fish species at each station is presented in Table 1.

The dominat family is Cyprinidae with 9 species (Table 1). The results of Cyprinidae in the Lakitan River were less than the results of a study in the Lakitan Dam where Cyprinidae captured were 11 species (Samitra \& Rozi, 2018b). The number of species of Cyprinidae caught in the Lakitan River in Musi Rawas Regency is commonly found in the river, especially in Sumatra, such as the Kelingi River, the Tenayan River and Siak River (Kottelat et al., 1993; Pulungan, 2009; Samitra \& Rozi, 2018a). Cyprinidae is a family that is easily adaptable and mostly found in freshwater. Cyprinidae di Sebanyak 107 spesies di Sumatra, 44 di Java dan 138 species in Borneo, so it is reasonable that this family dominates in some catches (Kottelat et al., 1993; Adis et al., 2017; Wahyuni \& Zakaria, 2018).

The species of Cyprinidae that most commonly caught in the Lakitan River is Barbonymus gonionotus (61 specimens). These fish can dominate because they are able to adapt well and can become herbivores when the availability of plankton, water insects and benthos (Froese \& Pauly, 2018). The number of Barbonymus gonionotus caught in the Lakitan River is more than one which caught in the Lakitan Dam (38 specimens) (Samitra \& Rozi, 2018b). This difference is due to the sampling point, the present study in the Lakitan River used 5 stations while the study at the Lakitan Dam was only used 1 station. The number of Barbonymus gonionotus caught is similar to some of the results from the previous studies, such as in the Kelingi River (Samitra \& Rozi, 2018a; Samitra et al., 2018) and many were caught during rainy season in the Bengawan Solo River (Adjie \& Utomo, 2010).

Bagridae is the second most common family found in the Lakitan River. 2 species of Bagridae that have been caught are Bagroides melapterus (27 specimens) and Hemibagrus velox (40 specimens) (Table 1). The number of Bagridae species found in this study is similar from the results of other studies where the number of species found was 2-3 species (Hadiaty, 2011; Nurudin et al., 2013; Eddy, 2013; Adis et al., 2017). Bagridae is a mustache fish, not scaly and has the ability to live in various conditions and can live in the riverbed (Kottelat et al., 1993; Adis et al., 2017).

The family of Belonidae found in the Lakitan River as much as 1 species, Xenentodon canciloides (Table 1). The morphology of species Belonidae are elongated, have long and sharp jaws, and live together in the surface of the water (Kottelat et al., 1993). The conservation status of Xenentodon canciloi- 


\section{JURNAL BI@DJATI}

http://journal.uinsgd.ac.id/index.php/biodjati

des is least concern (Froese \& Pauly, 2018). Xenentodon canciloides in the Lakitan River were caught only as many as 5 specimens. From this finding, to be a study related to its conservation status is needed.

In the Lakitan River, there was only 1 species belonged to Belontiidae family found, namely Trichopodus trichopterus (Table 1). The findings of Trichopodus trichopterus in the Lakitan River are actually quite strange because the characteristics of these fish live in stagnant water and are able to live in waters with low oxygen concentration (Kottelat et al., 1993). The possibility of this fish entering the Lakitan River might be from swamps/ ponds during a flood. Trichopodus trichopterus has now been found as a foreign fish in Brazil (Rodrigues-Filhoa et al., 2018).

There was 1 species of Channidae found, namely Channa striata (Table 1). Channidae is snakehead fish, these kinds of fish are able to breathe air from the atmosphere and usually live in the tropics (Kottelat et al., 1993). Channa striata is fish that dominantly lives in swamps and calm waters (Froese \& Pauly, 2018). Currently, Channa striata are used as a source of albumin supplement for health (Romadhoni et al., 2016).

Clarias batrachus is only species belonged to Clariidae in the Lakitan River (Table 1). Clariidae is a family of fish with characteristics of hard heads, cylindrical bodies and can walk using pectoral fins and pelvic fins (Kottelat et al., 1993). Some of the studies state that Clarias batrachus has become introduced in several places (Froese \& Pauly, 2018). This species potential for ornamental fish.

The family of Mastacembelidae was found in in the Lakitan River as many as 1 species, Mastaecembelus maculatus (Table 1). Mastacembelidae is a fish that resembles eel, has a long body with a flat tail, a snout that forms like a nose (Kottelat et al., 1993). Mas- taecembelus maculatus is a type of benthopelagic fish, and these fish are able to live in rivers with acidic condition (Froese \& Pauly, 2018).

The family of Pangsiidae found was 1 species, namely Pangasius micronemus (Table 1). Pangsidae are mustache fish, do not have scales and have murmurs (Kottelat et al., 1993). During the study, Pangasius micronemus caught was 10 specimens (Table 1). Pangasius micronemus is benthopelagic fish and can grow up to $1 \mathrm{~m}$ (Rainboth, 1996; Froese \& Pauly, 2018).

The family of Pristolepididae found was 1 species, namely the Pristolepis grooti (Table 1). Pristolepididae is close to Nandidae, in Indonesia, there are only 2 types of this family (Kottelat et al., 1993). During the study, Pristolepis grooti caught as many as 17 specimens (Table 1). Pristolepis grooti is an Indonesian native fish with good economic value (Alawi et al., 2014).

The family of Siluridae found in the Lakitan River was 1 species, namely Kyrptopterus schilbeides. Siluridae is a mustache fish with various, body sizes varies and lives on the riverbed (Kottelat et al., 1993). During the study, Kyrptopterus schilbeides captured was 4 specimens.

The familiy of Tetraodontidae found in the Lakitan River was 1 species, namely Pao leiurus (Table 1). Tetraodontidae are fish whose bodies have poisonous thorns and are able to expand when they feel threatened (Kottelat et al., 1993). Pao leiurus is a demersal fish that is aggressive and highly toxic. Sometimes it is export as ornamental fish (Froese \& Pauly, 2018).

Even though there are 6 endemic fish species in South Sumatra namely, Nundus mercatus, Betta renata, Rasbora jacobsoni, Puntius dorsimaculatus, Parosphoremus sumatranus, and Pseudomystus moeschii (Prianto et al., 2016). The fish that have been caught 


\section{Jurnal Biodjati 4(1):11-20, May 2019 \\ JURNAL BI@DIATI}

http://journal.uinsgd.ac.id/index.php/biodjati

during this study are not endemic. Moreover, no introduced fish were found such as those found in several rivers such as 2 species in the Kelingi River (Samitra \& Rozi, 2018a). This shows that the people around the Lakitan River did not release alien fish species into the river.

Table 1. Data on Number of Specimens, Species and Family of Fish in the Lakitan River

\begin{tabular}{lcccccc}
\hline \multirow{2}{*}{ Data } & \multicolumn{5}{c}{ Station } & \multirow{2}{*}{ Total } \\
\cline { 2 - 6 } & 1 & 2 & 3 & 4 & 5 & \\
\hline Number of Specimens & 44 & 34 & 42 & 121 & 173 & 418 \\
Species & 6 & 7 & 11 & 15 & 16 & 20 \\
Family & 2 & 2 & 7 & 7 & 8 & 11 \\
\hline
\end{tabular}

\section{Ecological Aspects}

The overall results of the study in the Lakitan River (Tabel 2), the diversity index is categorized as medium $\left(H^{\prime}=2.19\right)$. The result of categorical diversity index indicates that the number of fish species in the Lakitan River is quite large because it is supported by a balanced ecosystem. This is seen from the result obtained in stations 3 to 5 (Table 3), the species of fish caught are quite large, namely 11 species (station 3 ), 15 species (station 4) and 16 species (station 5 ). However, the diversity index at station $1\left(\mathrm{H}^{\prime}=1.69\right)$ and station $2\left(\mathrm{H}^{\prime}\right.$ $=1.8$ ) are in a low category. The low index value means that the number of species living in these two stations is small (Table 3). Diversity index value depends on the number of variations of species caught. If the number of species caught more, the level of fish diversity in water will be even greater (Sriwidodo et al., 2013; Erika et al., 2018).

Overall evenness index and among station in the Lakitan River $>0.9$ (Table 3), so that it can be interpreted that the uniformity between species of fish in the River Lakitan is evenly distributed. This evidence is strengthened by the results of the similarity index between stations in the Lakitan River which ranging from $0.65-0.7$ (Table 4). The lowest similarity index value between stations 1 and 5 is 0.65 and the highest similarity index value between stations 4 and 5 is 0.97 . These results show that the compositions of fish species between stations are almost the same, as evidenced by the high evenness index value which means the community is stable (Rappe, 2010).

Based on Table 3, the fish dominance index at each station ranged from 0.08-0.197 and was categorized as low. Overall, the fish dominance index in the Lakitan River is 0.13 (low category), this shows that the Lakitan River is not dominated by one particular species. This is in accordance with the statement of Fikriyanti et al. (2018), where if the dominance index value is close to 0 , few species or no species dominate. This can be seen in Table 1 that there are no species with very high species composition values. The absence of dominating fish because the river is not polluted which characterized by balanced ecological conditions and contain diverse life (Purwanto et al., 2014).

The results of measurements of the physical and chemical factors of the Lakitan River in Table 5. Water temperature in the Lakitan River ranges from $27.90-28.80^{\circ} \mathrm{C}$, these results are still below the temperature threshold that can support fish life. The optimum temperature for fish in tropical rivers is 24-30 ${ }^{\circ} \mathrm{C}$ (Pankhurst \& Munday, 2011). Temperature changes that will significantly affect fish activity and can cause fish to die (Masjudi et al., 2016).

Water $\mathrm{pH}$ in the Lakitan River ranges 


\section{Jurnal Biodjati 4(1):11-20, May 2019 \\ JURNAL BI@DIATI}

http://journal.uinsgd.ac.id/index.php/biodjati

from 7.03 - 7.56 (Table 5), this result shows that the condition of the river $\mathrm{pH}$ is good for fish life. The $\mathrm{pH}$ value of water that can support the life of organisms ranges from 6-9 (Wahyuni \& Zakaria, 2018). If the condition of $\mathrm{pH}$ is too low it will kill the organism because a low $\mathrm{pH}$ can increase the solubility of heavy metals in the waters so that it is toxic to aquatic organisms including fish (Kenconojati et al., 2016; Wahyuni \& Zakaria, 2018). High $\mathrm{pH}$ levels can increase the concentration of ammonia in water which is also toxic to aquatic organisms (Tatangindatu et al., 2013).

Dissolved Oxygen (DO) in Lakitan River ranges from 8.26 - $12.3 \mathrm{mg} / \mathrm{L}$ (Table 5 ). The data shows that the water quality in
Lakitan River is good so that fish can live and breed because fish can live in waters where DO content is at least $5 \mathrm{mg} / \mathrm{L}$ (Tatangindatu et al., 2013). Table 5 shows that the higher the DO content the more fish caught. This opinion was reinforced by Okyere (2018) DO increase will increase the diversity of fish species.

Data physical and chemical factors of water that the data obtained is still below the threshold for fish life. Possible differences in fish diversity at each station are nutrition, and fish migration (Yuanda et al., 2012; Hossain et al., 2017). Rashid et al. (2015) state several factors that cause fluctuations and replacement of species such as changes in water speed due to high rainfall.

Table 2. Fish Composition in Lakitan River

\begin{tabular}{|c|c|c|c|c|}
\hline Local Name & Species & Family & $\begin{array}{l}\text { Number of } \\
\text { Specimens }\end{array}$ & $\begin{array}{c}\text { Species } \\
\text { composition } \\
(\%)\end{array}$ \\
\hline Nyoloung & Xenentodon canciloides & Belonidae & 5 & 0.24 \\
\hline Cawang Hidung & Schismatorhynchos heterorhynchos & Cyprinidae & 32 & 7.73 \\
\hline Kapiat & Barbonymus gonionotus & & 61 & 14.73 \\
\hline Kapiul & Barbodes lateristriga & & 30 & 7.25 \\
\hline Kepalau & Osteochilus vittatus & & 23 & 5.56 \\
\hline Keperas & Cyclocheilichtys apogon & & 31 & 7.49 \\
\hline Ombut & Labiobarbus fasciatus & & 23 & 5.56 \\
\hline Seluang & Rasbora caudimaculata & & 18 & 4.35 \\
\hline Kebarau & Hampala microlepidota & & 29 & 7.00 \\
\hline Seluang & Rasbora dusonesis & & 22 & 5.31 \\
\hline Sepatung & Pristolepis grooti & Pristolepididae & 17 & 4.11 \\
\hline Gabus & Channa striata & Channidae & 19 & 4.59 \\
\hline Sepat & Trichopodus trichopterus & Belontiidae & 1 & 0.24 \\
\hline Baung Pisang & Bagroides melapterus & Bagridae & 27 & 6.52 \\
\hline Baung & Hemibagrus velox & & 40 & 9.66 \\
\hline Jiho Kocor & Pangasius micronemus & Pangsiidae & 10 & 2.42 \\
\hline Tapahae & Kyrptopterus schilbeides & Siluridae & 4 & 0.97 \\
\hline Lele & Clarias batrachus & Clariidae & 1 & 0.24 \\
\hline Tilan & Mastaecembelus maculatus & Mastacembelidae & 8 & 1.93 \\
\hline \multirow[t]{2}{*}{ Buntal } & Pao leiurus & Tetraodontidae & 17 & 4.11 \\
\hline & Total Individu & & 418 & \\
\hline
\end{tabular}




\section{Jurnal Biodjati 4(1):11-20, May 2019 \\ JURNAL BI@DIATI}

http://journal.uinsgd.ac.id/index.php/biodjati

Table 3. Ecology Index in the Lakitan River

\begin{tabular}{lcccccc}
\hline \multirow{2}{*}{ Index } & \multicolumn{9}{c}{ Station } & \multirow{2}{*}{ Average } \\
\cline { 2 - 6 } & 1 & 2 & 3 & 4 & 5 & 2.20 \\
\hline Diversity index & 1.70 & 1.81 & 2.23 & 2.64 & 2.62 & 0.94 \\
Evenness index & 0.96 & 0.93 & 0.93 & 0.97 & 0.95 & 0.13 \\
Dominance index & 0.29 & 0.18 & 0.12 & 0.08 & 0.65 & 0 \\
\hline
\end{tabular}

Table 4. Similarity Index Among Stations in the Lakitan River

\begin{tabular}{cccccc}
\hline Station & 1 & 2 & 3 & 4 & 5 \\
\hline 1 & & & & & \\
2 & 0.93 & & & & \\
3 & 0.81 & 0.82 & & & \\
4 & 0.66 & 0.67 & 0.68 & & \\
5 & 0.65 & 0.66 & 0.67 & 0.97 & \\
\hline
\end{tabular}

Table 5. Average Water Quality in the Lakitan River

\begin{tabular}{lccccc}
\hline \multirow{2}{*}{ Paramater } & \multicolumn{5}{c}{ Station } \\
\cline { 2 - 6 } & 1 & 2 & 3 & 4 & 5 \\
\hline Temperature, ${ }^{\circ} \mathrm{C}$ & 28.03 & 28.26 & 27.90 & 27.96 & 28.80 \\
$\mathrm{pH}$ & 7.56 & 7.03 & 7.33 & 7.50 & 7.76 \\
Dissolved oxygen, $\mathrm{mg} / \mathrm{L}$ & 8.26 & 8.30 & 9.03 & 12.3 & 9.3 \\
\hline
\end{tabular}

\section{ACKNOWLEDGMENTS}

The author thanks the Kementerian Riset, Teknologi dan Pendidikan Tinggi (Republic of Indonesia). The research were funded by Penelitian Dosen Pemula (PDP) 2018.

\section{REFERENCES}

Adis, M. A., Setyawati, T. R., \& Yanti, A. H. (2017). Keragaman Jenis Ikan Arus Deras di Aliran Riam Banangar Kabupaten Landak. Protobiont, 3(2), 209-217. Adjie, S. \& Utomo, A. D. (2010). Hasil Tangkapan Beberapa Jenis Alat Tangkap di Sungai Bengawan Solo. BAWAL Widya Riset Perikanan Tangkap, 3(1), 33-44. Alawi, H., Ariyani, N. \& Asiah, N. (2014). Pemeliharaan Larva Ikan Katung (Pris- tolepis grooti Bleeker) dengan Pemberian Pakan Awal Berbeda. Jurnal Akuakultur Rawa Indonesia, 2(1), 24-42. Badan Pusat Statistik Provinsi Sumatera Selatan. (2014). Nama dan Panjang Sungai DAS Musi di Provinsi Sumatera Selatan menurut Nama Sungai Utama dan Anak Sungai, 2014. Retrieved from https://sumsel.bps.go.id/ statictable/2015/03/16/18/nama-danpanjang-sungai-das-musi-di-provinsisumatera-selatan-menurut-nama-sungai-utama-dan-anak-sungai-2013-.html BeritaSatu.(2015).PemkabMusirawasFungsikan Irigasi Baru Bendungan Lakitan. Koran online. Retrieved from http://www. beritasatu.com/makro/304033-pemkab-musirawas-fung sikan-irigasi-baru-bendungan-lakitan.html. 


\section{Jurnal Biodjati 4(1):11-20, May 2019 \\ JURNAL BI@DIATI}

http://journal.uinsgd.ac.id/index.php/biodjati

Eddy, S. (2013). Inventarisasi dan Identifikasi Jenis-Jenis Ikan Saat Pasang Surut di Perairan Sungai Musi Kota Palembang. In Seminar Nasional Sains \& Teknologi V Lembaga Penelitian Universitas Lampung Lembaga Penelitian Universitas Lampung pp. 428-436.

Emilia, I., Suheryanto, S. \& Hanafiah, Z. (2013). Distribusi Logam Kadmium dalam Air dan Sedimen di Sungai Musi Kota Palembang. Jurnal Penelitian Sains, 16, 59-64.

Erika, R., Kurniawan, K. \& Umroh, U. (2018). Keanekaragaman Ikan di Perairan Sungai Linggang, Kabupaten Belitung Timur. Akuatik: Jurnal Sumberdaya Perairan, 12(2), 17-25.

Fikriyanti, M., Wulandari, S., Fauzi, I. \& Rahmat, A. (2018). Keanekaragaman Jenis Burung Pada Berbagai Komunitas di Pulau Sangiang, Provinsi Banten. Jurnal Biodjati, 3(2), 157-165.

Froese, R. \& Pauly, D. (2018). Fish Base. World Wide Web electronic publication. Retrieved from www.fishbase. org.

Guo, Q., Liu, X., Ao, X., Qin, J., Id, X. W. \& Ouyang, S. (2018). Fish diversity in the middle and lower reaches of the Ganjiang River of China: Threats and conservation, 1-17.

Hadiaty, R. K. (2011). Diversitas dan Hilangnya Jenis-Jenis Ikan di Sungai Ciliwung dan Sungai Cisadane [Study of Fish Diversity and The Lost of Fish Species of River Ciliwung and R . Cisadane ]. Berita Biologi, 10(4), 491-504.

Hossain, M. A., Akter, M., \& Iqbal, M. M. (2017). Diversity of Fish Fauna in Kusiara River (Fenchungonj Upazilla), Northeast Bangladesh. Journal of Aquaculture in the Tropics, 32, 1-13.

Iqbal, M. (2011). Ikan-ikan di Hutan Rawa Gambut Merang Kepayang dan sekitarnya. Merang REDD Pilot Project. Sumatra Selatan, 91. Kenconojati, H., Suciyono, Budi, D. S. \& Faisal, M. (2016). Inventarisasi Keanekaragaman Jenis Ikan Di Sungai Bendo Desa Kampung Anyar Kabupaten Banyuwangi. Jurnal Agro Veteriner, 5(1), 89-97.

Kottelat, M., Whitten, J. A., Kartikasari, N. \& Wiryoatmojo, S. (1993). Freshwater fishes of Western Indonesia and Sulawesi. Jakarta: Periplus Edition. Masjudi, H., Tang, U. M. \& Syawal, H. (2016). Kajian Tingkat Stres Ikan Tapah (Wallago Leeri) yang dipelihara dengan Pemberian Pakan dan Suhu yang Berbeda. Berkala Perikanan Terubuk, 44(3), 69-83.

Negi, R. \& Mamgain, S. (2013). Species Diversity, Abundance and Distribution of Fish Community and Conservation Status of Tons River of Uttarakhand State, India. Journal of Fisheries and Aquatic Science, 8(5), 617-626.

Nurudin, F. A., Kariada, N. \& Irsadi, A. (2013). Keanekaragaman Jenis Ikan di Sungai Sekonyer Taman Nasional Nasional Tanjung Puting Kalimantan Tengah. Unnes Journal of Life Science, 2(2), 118-125.

Okyere, I. (2018). Influence of diurnal tides and other physico-chemical factors on the assemblage and diversity of fish species in River Pra Estuary, Ghana. Tropical Ecology, 59(1), 83-90.

Pankhurst, N. W. \& Munday, P. L. (2011). Effects of climate change on fish reproduction and early life history stages. Marine and Freshwater Research, 62(9), 1015-1026. Pratami, V. A. Y., Setyono, P. \& Sunarto, S. (2018). Zonasi, Keanekaragaman dan Pola Migrasi Ikan di Sungai Keyang, Kabupaten Ponorogo, Jawa Timur. Jurnal Ilmu Lingkungan, 16(1), 78-85. Prianto, E., Puspasari, R., Oktaviani, D. \& Ai- 


\section{Jurnal Biodjati 4(1):11-20, May 2019 \\ JURNAL BIDDJATI}

http://journal.uinsgd.ac.id/index.php/biodjati

syah. (2016). Status Pemanfaatan dan Upaya Pelestarian Ikan Endemik Air Tawardi Pulau Sumatera. Jurnal Kebijakan Perikanan Indonesia, 8(21), 111-122.

Pulungan, C. P. (2009). Fauna Ikan dari Sungai Tenanya, Anak Sungai Siak, dan Rawa di Sekitarnya, Riau. Berkala Perikanan Terubuk, 37(2), 78-90.

Purwanto, H., Pribadi, T. A. \& Martuti, N. K. T. (2014). Unnes Journal of Life Science. Unnes Journal of Life Science, 3(1), 59-67.

Rahman, A. \& Mujiyanto. (2013). Komunitas Fitoplaknton di Taman Nasional Karimunjawa, Jepara, Jawa Tengah. Widyariset, 16(3), 395-402.

Rainboth, W.J. (1996). FAO species identificationfield guide for fishery purposes. Fishes of the Cambodian Mekong. Italy: FAO.

Rappe, R. A. (2010). Struktur Komunitas Ikan Pada Padang Lamun yang Berbeda di Pulau Barrang Lompo. Jurnal Ilmu dan Teknologi Kelautan Tropis, 2(2), 62-73.

Rashid, Z. A., Asmuni, M. \& Amal, M. N. A. (2015). Fish Diversity of Tembeling and Pahang Rivers, Pahang Malaysia. Checklist the Journal Biodiversity Data, 11(5), 1-6.

Rodrigues-Filhoa, C. A., Gurgel-Lourenço, R. \& Sánchez-Botero, J. (2018). First Report of the alien species Trichopodus trichopterus ( Pallas , 1770) in the state of Ceará, Brazil. Brazilian Journal of Biology, 78(2), 1-2.

Romadhoni, A. R., Afrianto, E., Pratama, R. I. \& Grandiosa, R. (2016). Extraction of Snakehead Fish [Ophiocephalus striatus (Bloch, 1793)] Into Fish Protein Concentrate as Albumin Source using Various Solvent. Aquatic Procedia, 7, 4-11.

Samitra, D. \& Rozi, Z. F. (2018a). Keanekaragaman Ikan Air Tawar Di Bendungan Lakitan Kabupaten Musi Rawas Provinsi
Sumatera Selatan. In Seminar Nasional Sains dan Teknologi Terapan pp. 92-96. Samitra, D. \& Rozi, Z. F. (2018b). Keanekaragaman Ikan di Sungai Kelingi Kota Lubuklinggau. Jurnal Biota, 4(1), 1-6. Samitra, D., Susanti, I. \& Sari, E. T. (2018). Iktiofauna di Sungai Kelingi Kabupaten Musi Rawas Provinsi Sumatera Selatan. In Seminar Nasional Sains dan Teknologi Terapan pp. 21-25. Sriwidodo, D. E., Budiharjo, A. \& Sugiyarto. (2013). Keanekaragaman Jenis Ikan di Kawasan Inlet dan Outlet Waduk Gajah Mungkur Wonogiri. Bioteknologi, 10(2), 43-50. Sukmono, T. \& Margaretha, M. (2017). Ikan Air Tawar di Ekosistem Bukit Tigapuluh. Yayayan Konservasi Ekosistem Hutan Sumatera \& Frankfrut Zoological Society. Retrieved from https://fzs.org/ files/7315/1460/0461/FZS-Ikan-AirTawar-Ekosistem-Bukit-Tigapuluh.pdf Tatangindatu, F., Kalesaran, O. \& Rompas, R. (2013). Studi Parameter Fisika Kimia Air pada Areal Budidaya Ikan di Danau Tondano, Desa Paleloan, Kabupaten Minahasa. Budidaya Perairan, 1(2), 8-19.

Wahyuni, T. T. \& Zakaria, A. (2018). Keanekaragaman Ikan di Sungai Luk Ulo Kabupaten Kebumen. Biosfera, 35(1), 23-28.

Yuanda, M. A., Dhahiyat, Y. \& Herawati, T. (2012). Struktur Komunitas Ikan di Hulu Sungai Cimanuk Kabupaten Garut. Jurnal Perikanan Dan Kelautan, 3(3), 229-236. 